\title{
Acculturation and Management Control- 'Japanese Soul in Sri Lankan Physique’
}

\author{
Chandana Rathnasiri Hewege \\ Swinburne University \\ Email: rathnasirichan@yahoo.com
}

\begin{abstract}
The study explores the way in which acculturation can be used as a management control mechanism. Acculturation - inculcating values and norms of one culture to another culture- has been studied in relation to national cultures whereas, the application of acculturation to the study area of management control is novel. By using the ethnographic research method, this research examines as to how a Sri Lankan subsidiary of a Japanese company acculturates its employees to Japanese work values with a view to instituting a positive work culture. The study has illustrated the process through which workers unlearned indigenous Sri Lankan work values and assimilated new Japanese work values. The findings are useful for designing strategies to acculturate employees to create an effective management control regime.
\end{abstract}

Keyword: Acculturation, Management Controls, Organisational Culture, Ethnography, Sri Lanka, Japan

\section{INTRODUCTION}

There has been considerable interest in how culture, organisational or national, shapes management control system of a firm (e.g. Ansari \& Bell, 1991; Bhimani, 1999; Efferin \& Hopper, 2006; Harrison \& McKinnon, 1999). The cultural perspective and its role in understanding management controls of a firm has been widely researched (e.g. Chow, Shields, \& Wu, 1999; Efferin \& Hopper, 2006; Harrison \& McKinnon, 1999; Ouchi, 1977; Ouchi, 1979) and yet there are unresolved methodological and theoretical controversies and, inconsistent and problematical results. Theoretically, this problem could be attributed to the use of deterministic categorisations of cultural values across nations by means of frameworks such as 
Hofstede (1980). Methodologically, this problem could be due to the use of survey research method that was insufficient to study deep-rooted cultural diversities within a given national culture and more specifically within a given organisation (Bhimani, 1999; Chua, Lowe, \& Puxty, 1989; Otley, 1994; Wickramasinghe \& Hopper, 2005). Also, the influence of contingency theory on management control research has labelled culture as a contingency variable, effects of which could easily be predicted (Bhimani, 1999; Chenhall, 2003; Efferin \& Hopper, 2006). Moreover, cultural contingency research based on surveys, often using cultural constructs from Hofstede (1980), has neglected issues of ethnicity and indigenous subcultures. Therefore, significant diversities within a given national culture tend to be neglected by many positivistic research designs (Wickramasinghe \& Hopper, 2005). Further, organisations within one national context can exhibit similarities in their functioning not shared by enterprises in other countries (Bhimani, 1999). Consequently, management controls have been found to possess characteristics that are countryspecific rather than supra-national (Harrison \& McKinnon, 1999). This emphasises the importance of culture in understanding management controls of an organisation within a given national culture.

Given the theoretical and methodological deficiencies specific to studying culture and its effect on management controls, the recent management control literature has witnessed strong calls for non-positivistic methods supported by multidisciplinary theoretical approaches to study the phenomenon of culture and its effect on management controls (Baxter \& Chua, 1998; Efferin \& Hopper, 2006; Veen-Dirks, 2006; Wickramasinghe \& Hopper, 2005; Wickramasinghe, Hopper, \& Rathnasiri, 2004). There have been particular interests in how national culture impinges on management control of an organisation and several studies have investigated this phenomenon (e.g. Chow et al., 1999; Efferin \& Hopper, 2006; Wickramasinghe \& Hopper, 2005). However, the phenomenon of acculturation related to management controls is under researched. Acculturation, as a widely used term in anthropology, connotes how people of one national culture infuse their cultural values to a group of people from another national culture.

The central issue addressed in this paper is 'how can acculturation be used in organisations as a mechanism of management control?' Conversely, this issue can be articulated as 'how can employees of a weak work culture be acculturated to a strong work culture?' The rest of the paper is organised in six sections. First, a review of management control and organisational culture is presented. Second, the concepts of acculturation and cultural assimilation are explained. Third, the socio-economic 
antecedents of Sri Lankan work culture is elaborated setting out the context of the study. Fourth, the research methodology is explained followed by the empirical findings and, the discussion and conclusions in the fifth and sixth sections respectively.

\section{MANAGEMENT CONTROL AND ORGANIZATIONAL CULTURE}

Management control (MC) is a general term for a wide rage of formal and informal approaches, and mechanisms that are aimed to regulate behaviour of members of an organisation. Some of the formal mechanisms include structure, reward systems, budgeting, standard operating rules and procedures, strategic planning system and operational controls. Informal techniques are leadership, culture, values and norms (Macintosh, 1994). MC can be viewed as a process of assuring that resources are obtained and used effectively and efficiently in the accomplishment of the organisation's objectives (Anthony, 1965). Also management control can be viewed as a process by which managers influence other members of the organisation to implement the organisation's strategies (Anthony \& Govindarajan, 1998; Flamholtz, Das, \& Tsui, 1985; Ouchi, 1977).

Organisations can be viewed as structures of control (Salaman, 1978) and they have cultures that resemble an amalgam of beliefs, ideologies, languages, rituals and myths (Pettigrew, 1979). Controls based on organisational culture could elicit desired behavioural compliance that synchronise organisational goals with employee goals. A popular debate on organisational culture is whether culture is something an organisation has, or whether culture is something an organisation is (Smircich, 1983). In other words, is culture a variable or a metaphor? In this paper, I assume culture as a variable that can be regulated or manipulated. The use of culture as a form of employee control was evident in earlier works of Gregory (1983), Wilkins and Ouchi (1983), Etzioni (1960) and Smircich (1983). Recent research such as Bhimani (1999) and Efferin et al (2006) extends this debate. However, these researchers have not considered the concept of acculturation in conceptualising cultural controls, although the cultural approach to management control has received unprecedented research attention during the past four decades. For example, earlier works of Etzioni (1960) investigated the control function of culture in organisations followed by Ouchi's works on culture and controls (Ouchi, 1977; Ouchi, 1979). During the1980s, there was a 'revival' of cultural perspective on management in general. For example, Peters and Waterman (1982) brought the notion of culture to the forefront of popular management thought and Hofstede (1980) developed a useful categorisation of cultural values across national boundaries. 
In contrast to bureaucratic controls where domination is shifted from manager's arbitrariness to rational rules and procedures, cultural control tends to secure control through voluntary commitment by the employees and ensures goal congruence between the employees and the organisation. The change of emphasis from 'management controls' to 'control of values, attitudes and norms' has made organisational culture an important tool of organisational control (Das \& Teng, 1998; Powell, 1996). This shift, according to Kunda (1992) is the regulation of the employees' self, rather than the work they are engaged in. In a small organisation where owner-manager is able to secure daily direct contact with employees, it is easy to receive personal loyalties of employees who tend to identify themselves with both the owner and one another. This 'simple control' (Edwards, 1979) can prevail until the organisation grows beyond a certain size. The owner-manager can easily groom employees to embrace the desired culture through emotional ties as they are bound by the close- knitting of the web of direct personal contacts. However, as the organisation grows, these direct controls need to be replaced by structural controls characterized by either technical (operated by technical requirements of machinery) or bureaucratic controls (through hierarchical control or rule of law). To retain some features of direct controls, large organisations could use corporate culture as a management control mechanism (Simons, 1995). It was suggested that by inculcating an appropriate belief system among the employees, organisation culture can facilitate management control (Simons, 1995). Belief systems link core values of the employees to business strategy and inspire them to realise organisation's purpose. Thus, it can be argued that by inculcating an appropriate belief system through acculturation, an organisation can establish a cultural control system that can ensure proper goal congruence.

\section{ACCULTURATION AND CULTURAL ASSIMILATION IN ORGANISATIONAL CONTEXT}

Infusion of cultural values from one culture to another culture is simply denoted as acculturation. The culture whose values are imposed on another culture can be regarded as a dominant culture while the other culture that is being influenced by the dominant culture can be termed as a weak culture. According to Kroeber (1948) acculturation comprises those changes in a culture brought about by another culture and will result in an increased similarity between the two cultures. This change could be reciprocal, however, very often the process is not symmetrical and the result is the absorption of one culture into the other. Kroeber (1948) states that acculturation is gradual rather than abrupt. Conversely, acculturation can be viewed as a process of 
systematic cultural change of a particular society carried out by an alien, dominant society (Winthrop, 1991). This change may occur under the conditions of direct contact between individuals of each society (Winthrop, 1991). Through acculturation, individuals of a weak culture learn the language, habits, and values of a dominant culture.

Acculturation precedes assimilation which is the process by which individuals of a weak culture ascend to social positions and acquire the political, economic, and educational standards of the dominant culture. These individuals, through the social process of assimilation, tend to integrate themselves with the dominant culture (Thompson, 1996). For this to happen, an individual needs to go through a series of stages namely, behavioural assimilation, structural assimilation (social assimilation) and marital assimilation (Gordon, 1964). Assimilation does not necessarily follow acculturation. In some instances, a weak culture may not absorb the values of the dominant culture. Therefore, there could be a period of transition during which the weak culture tends to lose faith in its own values and at the same time is unable to adopt the values of the dominant culture. During this transition period there could be a feeling of dysporia, in which individuals in the weak culture exhibit feelings of insecurity and unhappiness (Titiev, 1958).

Acculturation has been extensively studied in relation to national cultures (e.g. Gordon, 1964; Thompson, 1996). However, its application in organisational context is novel. Infusion of organisational practices, values, attitudes and norms from one organisational culture to another organisation culture could be described as organisational acculturation. The presence of a culture catalyst, who could be a CEO or a senior manager, could enhance the organisational acculturation process by being a driving force to infuse cultural practices from the dominant to the weak culture. It may also be possible that acculturation could take place in the absence of a culture catalyst giving rise to a natural transfusion of values, norms, behaviours and attitudes from one culture to another.

The training and grooming of employees with a view to facilitating them to assimilate new attitudes, values and norms can be considered critical to effective acculturation and assimilation. It is also possible to identify some soft aspects and hard aspects in organisational acculturation. For example, acculturation of work values and attitudes could constitute the soft aspects while acculturation of specific work techniques could be considered as the hard aspects of acculturation. An organisation can use acculturation to inculcate certain values and beliefs that aid the achievement of specific organisational performance targets. These could include 
among other things product quality, work norms and behavioural targets. In a situation where the current organisation culture does not facilitate the accomplishment of performance targets, it is desirable to acculturate employees to cultural values of a dominant organisational culture. However, there could be a risk of dysporia (feelings of insecurity and unhappiness) in the minds of the employees if they both failed to assimilate new culture and lost the grip on their own culture. The risk of dysporia could escalate, if performance declined. It can be said that acculturation is complete when values, attitudes, norms and behaviours are assimilated together with work techniques and practices. In this study, the focus is on the acculturation of Japanese organisation culture (Japanese soul) by the Sri Lankan employees (Sri Lankan Physique) and on the subsequent assimilation of Japanese work values and norms by them.

\section{SRI LANKAN WORKCULTURE: SOCIO-ECONOMIC ANTECEDENTS}

Sri Lanka is an island nation in the Indian Ocean situated in Southern Asia, 31 kilometres off the southern coast of India with a population of 20 million people who live in a geographical spread of $65,610 \mathrm{~km}^{2}$. Sri Lanka is a lower middle income developing nation with a gross domestic product of US \$ 40.7 billion and a per capita income of US \$ 1,780 in 2008 (WorldBank, 2009). In Sri Lanka, Sinhalese kings ruled for over 2000 years, followed by 450 years of colonial rule by the Portuguese, the Dutch and the British, respectively. In 1948, Sri Lanka gained independence. Until 1505, Sri Lanka had been an independent state with agriculture as the predominant economic activity. During the period 1796-1948, the British administration restructured the economy by shifting it from a subsistence agricultural level to a trading economy based on tea, natural rubber and spices. Private companies were formed in the early period of the $18^{\text {th }}$ century and in the late 1800 s Sri Lanka had a stock market. With these developments, a dual economy began to emerge in the welldeveloped corporate export-based sector and the mass agricultural-based subsistence sector (based in rural areas). Almost, $75 \%$ of the population is rural and agriculture dominates. As a result, feudal thinking and values, originating from pre-colonial monarchical system, tend to prevail in the minds of the majority of people. This traditional mentality often confronts with modern private entrepreneurial values.

During the British colonial period, the masses generally perceived that the British-based private companies were exploiting them. This resulted in an emergence of anti-capitalistic ideas in the 1920s (following the footsteps of the Russian revolution). Post-independent Sri Lanka experienced an era of socialist-based inward 
looking development policies. The state became the source of ultimate welfare for the people. A large number of nationalised ventures were incorporated in the 1960s, especially in the larger industries such as cement and steel (Jupp, 1978). All private enterprises including foreign-based companies (i.e. tea plantations) were nationalised (Jupp, 1978; Kelegama, 1993; Navarathne, 1986). The main employer was the government and the private sector was not trusted as a source of sustainable employment. In 1977, Sri Lanka liberalised the economy and has since made the private sector the engine of growth. Yet, there is a large segment of the rural population who do not participate in this process (Hettige, 2000; Moore, 1993).

The trade unions in Sri Lanka are segregated based on factors such as political ideology, industry, job category and sector. Strikes are common, for instance, 57 strikes in 2005 (DOL, 2006). The presence of a large number of trade unions, about 1800 in 2006, and high levels of industrial disputation could be attributed to the dominant role played by the trade unions in Sri Lanka, a unique socio-politico and socio-economic aspect of the Sri Lankan work ethic (DOL, 2006) . The political role of trade unions, their militancy and their pervasiveness in the social lives of the people are critical in understanding the work behaviour of the Sri Lankan employees. Majority of youth are influenced by anti-capitalist ideology and they embrace anticapitalist sentiments (Moore, 1993). Also, having influenced by the feudal mentality, they tend to be less flexible and always expect 'white collar' administrative jobs. It can be said that capitalist ethos is undermined by feudalist values. In general, the cultural values that employees bring into private organisations are not 'conducive' for profit motive and efficiency (Chandraprema, 1989; Hettige, 2000; Wickramasinghe et al., 2004). The managers of private sector companies often complain that the organisational culture is affected by the 'low work values' (FSS, 2000; Wickramasinghe \& Hopper, 2005; Wickramasinghe et al., 2004). Previous studies on management controls of Sri Lankan entities revealed numerous problems concerning the work culture of employees and mangers (Hewege, 2005, 2006; Wickramasinghe \& Hopper, 2005; Wickramasinghe et al., 2004). Under these circumstances, it can be said that the work values and culture that manifest in the behaviour of average Sri Lankan workers are not compatible with the private sector corporate culture. Thus, many Sri Lankan managers are faced with the challenge of controlling employee behaviour. 


\section{METHODOLOGY}

The study uses the interpretive tradition of research, i.e. ethnography method (Clifford \& Marcus, 1986; Geertz, 1988) to understand the acculturation practices in organisational and social context. Ethnographic method can be used to analyse how various actors choose to behave in the way that they do things and to understand the orderly patterned nature of actors' everyday social behaviours (Jonsson \& Macintosh, 1997). Data collection was done through in-depth interviews and observations following the methodological approach that resembles adaptive theory, a modified version of the grounded theory (Layder, 1997, 1998). As in grounded theory (Glaser \& Strauss, 1967), I did not start data collection with a 'bear mind'. Instead, I entered the field (case company) with some preconceived ideas about what to seek for. This means that the general theories on acculturation, management control and organisational culture offered a skeletal framework (Jorgensen, 1989; Laughlin, 1995) for data collection. Thus, the interview questions and the directions of the interviews were clearly set to investigate the phenomenon of acculturation in organisational context.

After a lengthy initial discussion (2-3 hours) with the CEO, I consulted theories of acculturation and management control to demarcate the investigative domain of the study. Next, I conducted three in-depth interviews with the CEO with a view to identifying the actors and the phenomena for deeper probe. The transcripts of these interviews provided useful themes that formed the basis of the second stage of interviews in which 15 in-depth interviews with employees were conducted (nine interviews with factory workers and six with office staff). Data analysis was performed in accordance with adaptive theory method (Layder, 1997, 1998). The use of non-participant, overt and covert observations aided the triangulation of interview data. The observations included daily morning meetings, the speeches made by the CEO and employees in the daily morning meetings, the atmosphere prevalent in the meeting, the layout of the office furniture, the manner in which the guests are treated by the employees, the natural work behaviour of employees, the general office procedures and the photographs of the social events of the employees.

\section{EMPIRICAL ANALYSIS}

\section{Background}

HL Company (HLC) is a fully-owned subsidiary of Itho Spring Co. of Japan, which supplies components and parts to several leading car manufacturers such as Toyota, Mitsubishi and Nissan. HLC produces a high precision component that is used 
in air bags of motor vehicles. The new factory and the office complex are located in an Export Processing Zone in the Western Province, 20 kilometres away from the city of Colombo, Sri Lanka. HLC has a workforce of 64 employees, 57 of whom are young girls. The organisation has a flat structure with very limited organisational levels. Direct, one-to-one contact with the CEO is made possible by this flat structure. Employees report directly to the CEO whose Charisma and affable personality tend to command loyalty from the employees.

CEO commented;

There is family feeling and culture. Some parents of the employees tell me their family problems, problems associated with their daughters such as love affairs etc... these girls (employees) do not hesitate to discuss such personal matters with me'

The role of Japanese Factory manager is nominal. The CEO is responsible for overall quality. Appointing a Japanese factory manager is the strategy employed by the head office to convince the buyers that HLC is managed by the Japanese. When asked about this, some employees expressed;

The Japanese buyers find it difficult to believe that a Sri Lankan CEO manages this company so competently

\section{Laying foundation for a 'Trust Culture'}

The Japanese parent company has already laid out clear norms and standards for technical operations. Therefore, the main task of the HCL is to control employee performance and to achieve the desired level of output. The small work force in the factory has facilitated the CEO's effort in building close relationships with the employees. The CEO takes conscious effort to remember a great detail of personal information about each and every worker in the factory. As a result, there is a strong one-to one psychological contract with each and every employee. These relationships are further cemented by a strong emotional bondage. Since everyone is emotionally attached to the CEO, there is a natural control of employees through loyalty. The values such as sense of belonging to the organisation and work commitment have emerged as a result of the bondage and loyalty to the CEO. There is a strong 'communal feeling' among employees. 


\section{Dismantling 'Psychological Structures'}

There is a significant disparity in status levels between managers and nonmanagers. Often, in most organisations, there is a job position designated as 'peon' whose task is to assist with minor work in the office such as moving files from one table to another, posting and delivery of documents and letters, and cleaning the office. When I was observing the factory premises, the CEO asked the head of the office, an economics graduate, to prepare some tea and bring it to the boardroom. In the meantime, two machine operators entered into the CEO's room and they were so friendly and freely talked to the CEO who then called them to the boardroom and had some soft drinks with them. Normally, in Sri Lankan work practices, employees show fear, respect and shyness in the presence of senior managers. In this organisation, it was observed that no cleaners (Janitors) are hired and the employees themselves do the cleaning. Given the Sri Lankan work values and practices, cleaning work is considered to be a low status work (due to feudal beliefs) and in most of the organisations there are separate workers for cleaning. It was observed that the cleanliness and the orderliness of the factory premises were remarkable.

\section{Strategies of Acculturation}

The CEO believed that the existing work culture of employees was not appropriate for achieving performance targets and therefore, wanted to make employees unlearn inappropriate work values and make them learn the positive aspects of Japanese work culture. The change of factory location, recruitment policy, rituals and practices were used as the key strategies to acculturate employees to the new work culture. It is phenomenal that out of 64 employees, 57 are young girls who have just completed Advanced Level Examination (equivalent to high school university entrance examinations) or undergraduate degree. When asked about the reasons, the CEO expressed;

In Japan also girls are preferred to undertake high precision jobs. Our product is a very sensitive component that is used in airbags in motor vehicles. The quality level required is one defect per million parts. Girls are better handlers of delicate work; aren't they delicate themselves!!!

Every year, the CEO joins the company excursion and spends a weekend in a five star rated hotel away from Colombo with the employees. According to him, this annual excursion is an unimaginably luxurious vacation for these employees and a 
stunning experience to all employees given their socio-economic status. An employee said;

We really love our annual trip; we feel we are in 'heaven', we love our CEO and he is a close friend!

The employees (girls) organise social events such as dramas and music fiesta. The CEO himself is a talented guitarist and a singer. He sings along with girls and all the girls admire his music talent. For them, the CEO is a performing artist and is loved by all. A strong trust-based relationship is developed through this process. An employee expressed;

Every month sir (CEO) sings with us and we love to take part in the singing with him

CEO added;

They have a deep friendship with me. It is this friendship that enables me to affect management controls. They are obedient, creative and flexible. They do not let down their best friend (me). They try to emulate me and I always behave showing positive aspects of Japanese work values

Every morning there is a common meeting for all the employees at the factory floor. This is a Japanese corporate practice that is uncommon to many Sri Lankan workers. New employees are introduced to other colleagues at the meeting and performance targets and current achievements of each production line are announced. There are many recitals in Japanese language (these meetings were observed and the recitals were recorded). All employees behaved as if they were Japanese workers; frequent bowing, Japanese greetings, work norms and standards. Daily morning meeting is one of the main instruments of control. The CEO attends the daily morning meeting and he always arrives in office ahead of the scheduled time. Most of the employees report to work well ahead of the official work commencement time. In the daily morning meeting, the CEO uses the following expression to get desired behaviour from employees; 'This is what you have to do.....; if you fail to do, that is nothing but you let me (CEO) down. It's like betraying me!'

Key to successful control is the use of psychological bondage and loyalty. CEO consciously strengthens and nurtures organisational culture that develops this bondage, 
trust and loyalty. This organisation does not have work supervisors since employees are trusted for responsible job performance. The Japanese work practices such as 5S and the quality circles are not forcefully imposed upon employees as in many other Sri Lankan companies. These practices are embedded in the day-to-day work practices. It can be said that the Sri Lankan employees have successfully assimilated the Japanese work practices to their natural work behaviour.

The recruitment and selection strategy tends to support the acculturation process. The selection process comprises a semi-structured interview, employment test and a simple IQ test. What is important in taking the selection decision is the background reference or recommendation by someone known to the CEO. Temperament, discipline and family background are important aspects to be considered in recruitment as effectiveness in grooming employees largely depends on them. Proximity to work place is another important factor that influences the selection decision. 'Employees are mentally and physically fresh if they live close to the work place'; CEO commented. The company prefers to hire candidates who are in the age range of 18 to 28 years. According to the CEO, this age range is ideal for training and grooming. Especially, attitudes, work values and creativity aspects can well be influenced. The company specially likes to hire candidates who are new to the job market. This is due to the fact that the newcomers are not preoccupied with inappropriate work attitudes and values. The company looks for 'fresh hearts and minds' that rightly fit into the main 'Jigsaw'. Included in the selection interview panel are three employees (peers). The reason for having these three employees in the panel is to test whether the new employee fits to the existing work culture.

\section{Assimilation of Japanese cultural values}

As explained earlier, generally the Sri Lankan work values and norms tend to hinder the achievement of performance targets. Employees are less likely to naturally develop a commitment or attachment to their work places. In the context of this negative work culture, creation of a positive work culture can be considered rational and desirable.

The CEO himself spent several years with a 'host family' (a Japanese family assigned to look after the emotional wellbeing of foreign students in Japan) in Japan during the period of his studies and became a 'true son' of the Japanese host father and mother. He assimilated Japanese family values and as a result was convinced of the idea of changing people through culture. 
It appears that there is no conflict between employees' original work culture and the newly assimilated work culture. The CEO actively involves in managing the assimilation process by setting an example by himself. He creates an environment of utmost trust and confidence to help employees assimilate Japanese work culture. The direct benefit of this trust is reflected in the management where there are no supervisors to inspect the production process. The control of 'self' or the normative control is achieved through mutual trust. A group of employees expressed;

We have achieved all the production targets set by the parent company well ahead of deadlines. We achieve targets better than Japanese workers in Japan. Head office is surprised

The office layout in the factory premises conform strictly to the Japanese way of management with several levels of meeting rooms for receiving visitors depending on their relationship with the CEO. HLC has outperformed its Japanese counterparts (workers) in production volume and quality targets. This is considered to be a remarkable event for HLC. The CEO of the Japanese parent company and his top management team were surprised about this achievement and had visited HLC to congratulate the Sri Lankan CEO and his workers. This event provides evidence to prove that HLC has achieved remarkable performance level through the control system based on the newly acculturated values and norms. In the year 2007, the CEO was awarded the entrepreneur of the year award by the Sri Lankan government in recognition of the outstanding performance of the HLC Company.

\section{DISCUSSION \& CONCLUSION}

The paper examined the way in which acculturation can be used as a management control tool. Given the inappropriate work culture and values prevailing in the Sri Lankan firms, infusing a new culture on top of an existing culture is the phenomenon that this study focused on. The interventionist or the culture catalyst approach of the CEO in building the culture for achieving better management control was also covered by the study.

The CEO's endeavour to acculturate Sri Lankan workers can be considered rational given the inappropriate work culture. In theory, assimilation follows acculturation and this has taken place in this organisation. In the case of national culture, acculturation is triggered by the influences of the dominant culture. However, in organisational context, this influence tends to emanate from the management 
leadership or the CEO whose acculturation initiatives are crucial to the effectiveness of the process.

The workers have unlearned the original Sri Lankan work values and have assimilated new Japanese work values without undergoing a 'dysporia' where employees could suffer from feelings of insecurity and unhappiness in the transition period. In theory, if dysporia took place, the employees could loose their original work values and still would fail to assimilate the values of the new culture. This problem did not arise as the acculturation was not a natural process rather it was a consciously planned effort by the CEO. Thus, this study illustrates the successful cultural acculturation and assimilation of values and practices. The positive outcomes of the acculturation can be gauged by the performance that exceeded the set targets. Given the assimilation being the acquisition of socio-economic status of the dominant culture by the people in the weak culture, it can be argued that outperforming the Japanese counterparts by the Sri Lankan employees in achieving production targets is similar to the assimilation of cultural values subsequent to acculturation.

In line with Kunda (1992), the study showed evidence for the regulation of the employees' self, rather than the work that they were engaged in. The trust culture created by the CEO was instrumental for controlling employees. Truly, the control was achieved through non-control or self-control of the employees. This is synonymous with normative control of Kunda (1992). The simple one-to-one control (Edwards, 1979) took place in the organisation, when the CEO maintained direct personal relationships with employees. Relatively small work force in the organization enabled the CEO to maintain direct personal relationships with each and every employee and thereby developing close emotional ties with them. Loyalty and trust were the mechanisms through which controls were administered. The Sri Lankan work values were replaced by the new culture based on trust, commitment, positive work values, comradeship and loyalty. It appeared that the social and personal lives of employees were intermingled and interwoven with organisational life through familytype culture.

The daily morning meetings symbolised a complete assimilation of Japanese organisational and cultural practices. The CEO used morning meetings to influence the employee behaviour through his charisma. The trust culture served as a foundation on which loyalty and self-control thrived. The total web of controls was maintained through this consciously created trust culture. It has been observed that the CEO's active intervention as an acculturation catalyst was the axial pole around which culture transfusion occurred. 
In conclusion, the study showed that the new organisational culture, created through acculturation, enabled an efficient system of management controls. It can be said that the transfusion of Japanese work values (Japanese soul) to Sri Lankan employees (Sri Lankan Physique) was successful and this was evident from the achievement of performance targets by the Sri Lankan employees by outperforming Japanese workers of the parent company. The structural and technical controls did not appear to be dominant given the main role played by the normative or direct control through the trust culture. The management of HLC triumphantly recorded the success story of employee control through organisational acculturation.

\section{REFERENCES}

Ansari, S. L., \& Bell, J. (1991). Symbolism, collectivism and rationality in organisational control. Accounting Auditing \& Accountability Journal, 4(2), 4-27. Anthony, R. N. (1965). Management planning and control systems: A framework for research. Boston, MA: Harvard Graduate of Business.

Anthony, R. N., \& Govindarajan, V. (1998). Management control systems (9th ed.). Burr Ridge, Ill.: Irwin McGraw-Hill.

Baxter, J. A., \& Chua, W. F. (1998). Doing Field research: practice and meta-theory in counter point. Journal of Management Accounting Research, 10(1), 69-87.

Bhimani, A. (1999). Mapping methodological frontiers in cross-national management control research. Accounting Organisation and Society, 24(56), 413-440.

Chandraprema, C. A. (1989). Ruhuna: A study of the history, society, and ideology of Southern Sri Lanka. Nugegoda, Sri Lanka: Bharat Publishers.

Chenhall, R. H. (2003). Management control systems design within its organisational context: findings from contingency-based research and directions for the future. Accounting Organisations and Society, 28(2/3), 127-168.

Chow, C. W., Shields, M. D., \& Wu, A. (1999). The importance of national culture in the design of and preference for management controls for multi-national operations. Accounting Organisations and Society, 24(5/6), 441-461.

Chua, W. F., Lowe, T., \& Puxty, A. G. (1989). Critical perspectives in management control. Basingstoke: Macmillan.

Clifford, J., \& Marcus, G. (1986). Writing Culture: The Poetics and Politics of Ethnography. Berkeley, CA: University of California Press.

Das, T. K., \& Teng, B. G. (1998). Between trust and control: developing confidence in partner cooperation in alliances. Academy of Management Review, 23(3), 491512. 
DOL. (2006). Labour Statistics. Retrieved July 02, 2008, from http://www.labourdept.gov.lk/statistics.htm

Edwards, R. (1979). Contested Terrain. London: Heinemann.

Efferin, S., \& Hopper, T. M. (2006). Management control, culture and ethnicity in a Chinese Indonesian company. Accounting Organisations and Society, 32(3), 223262.

Etzioni, A. (1960). A comparative analysis of complex organisations. New York: The Free Press.

Flamholtz, E., Das, T., \& Tsui, A. (1985). Toward an integrative framework of organisation control. Accounting Organisation and Society, 10(1), 35-50.

FSS. (2000). Country report on the trade union situation in Sri Lanka. Colombo: Friedrich-Ebert-Stiftung.

Geertz, C. (1988). Works and Lives:The Anthropologist as Author. Stanford: Stanford University Press.

Glaser, B. G., \& Strauss, A. C. (1967). The discovery of grounded theory: strategies for qualitative research. New York: Aldine Publishing Company.

Gordon, M. (1964). Assimilation in American Life: The role of Race, Religion, and National Origins. New York: Oxford University Press.

Gregory, K. L. (1983). Native view paradigms: multiple cultures and culture conflicts in organisations. Administrative Science Quarterly, 28(3), 359-376.

Harrison, G. L., \& McKinnon, J. L. (1999). Cross-cultural research in management control systems design: A review of the current state. Accounting Organisations and Society, 24(5/6), 483-506.

Hettige, S. (Ed.). (2000). Dilemmas of post-colonial society after 50 years of independence: a critical analysis Colombo: Macmillan India Limited.

Hewege, C. R. (2005). Dynamics of a leader's power in a bureaucratic organisation: charismatic power overriding the legal rational power. Paper presented at the International Conference on Business Management in the Third World, Colombo, Sri Lanka.

Hewege, C. R. (2006). Management Control Issues of a Privatised Entity in Sri Lanka: Hedeki Kamitsuma of NTT at SLT - Managing Transition Period of Privatisation. Paper presented at the 5th Asia Academy of Management Conference, Tokyo, Japan.

Hofstede, G. (1980). Culture's consequences: International differences in workrelated values. Beverly Hills: CA: SAGE. 
Jonsson, s., \& Macintosh, N. B. (1997). Cats, rats, and Ears: Making the case for ethnographic accounting research. Accounting Organisations and Society, 22(3/4), 367-386.

Jorgensen, D. L. (1989). Participant observation: a methodology for human studies. Newbury Park: Sage.

Jupp, J. (1978). Democratic Socialism in Sri Lanka. Pacific Affairs, 50(4), 15-31.

Kelegama, S. (1993). Privatisation in Sri Lanka: the experience during the early implementation. Colombo: Sri Lanka Economic Association.

Kroeber, A. L. (1948). Anthropology: Race, Language, Culture, Psychology, Prehistory. New York and Burlingame: Harcourt, Brace \& World, Inc.

Kunda, G. (1992). Engineering culture: control and commitment in a high-tech corporation. Philadelphia: Temple University Press.

Laughlin, R. C. (1995). Empirical research in accounting: alternative approaches and a case for middle-range thinking. Accounting Auditing \& Accountability Journal, 8(1), 63-87.

Layder, D. (1997). Modern sociological theory: key debates and new directions. London: UCL.

Layder, D. (1998). Sociological practice: Linking theory and social research. London: Sage.

Macintosh, N. B. (1994). Management accounting and control systems- An organisational and behavioural approach. New York: John Wiley \& Sons.

Moore, M. (1993). Thoroughly modern revolutionaries: The JVP in Sri Lanka. Modern Asian Studies, 27(3), 593-642.

Navarathne, V. T. (Ed.). (1986). Public enterprises in Sri Lanka. Delhi: Himalaya Publishing House.

Otley, D. (1994). Management control in contemporary organisations: towards a wider framework. Management Accounting Research, 5(3/4), 413-428.

Ouchi, W. G. (1977). The relationship between organisational structure and organisational control. Administrative Science Quarterly, 22(1), 95-113.

Ouchi, W. G. (1979). A conceptual framework for the design of organisational control mechanisms. Management Science, September 1979(25), 833-848.

Peters, T., \& Waterman, R. H. (1982). In Search of Excellence. London: Harper and Row.

Pettigrew, A. (1979). On studying organisational cultures. Administrative Science Quarterly, 24(2), 570-581.

Powell, W. W. (Ed.). (1996). Trust-based forms of governance. London: Sage. 
Salaman, G. (1978). Toward a sociology of organisational structure. Sociological Review, 26(3), 519-514.

Simons, R. (1995). Levers of control. Boston: Harvard Business School Press.

Smircich, L. (1983). Concepts of culture and organisational analysis. Administrative Science Quarterly, 28(2), 328-358.

Thompson, R. H. (Ed.). (1996). Assimilation (Vol. 1). New York: Henry Holt and Company.

Titiev, M. (1958). Introduction to Cultural Anthropology. New York: Henry Holt and Company.

Veen-Dirks, P. (2006). Complementary choices and management control: field research in a flexible production environment. Management Accounting Research, 17(1), 72-105.

Wickramasinghe, D., \& Hopper, T. (2005). A cultural political economy of management accounting controls: a case study of a textile Mill in a traditional Sinhalese village. Critical Perspectives on Accounting, 16(4), 473-503.

Wickramasinghe, D., Hopper, T., \& Rathnasiri, C. (2004). Japanese cost management meets Sri Lankan politics: Disappearance and reappearance of bureaucratic management controls in a privatised utility. Accounting Auditing \& Accountability Journal, 17(1), 85-120.

Wilkins, A. L., \& Ouchi, W. G. (1983). Efficient Cultures: exploring the relationship between culture and organisational performance. Administrative Science Quarterly, 28(3), 468-481.

Winthrop, R. H. (1991). Dictionary of Concepts in Cultural Anthropology. New York: Greenwood.

WorldBank. (2009). Key Development Data and Statistics: Sri Lanka Country Profile. Retrieved January 01, 2010, from http://web.worldbank.org 